\title{
The watershed: a factor in coronary vein graft occlusion
}

\author{
Simon Rees \\ From the National Heart Hospital, London
}

In 50 patients with one or more aortocoronary saphenous vein grafts investigated by angiography the patency rate of grafts inserted into arteries with a total proximal occlusion was significantly higher than of those inserted into arteries with a proximal stenosis. The interval between operation and investigation in the two groups was similar. In 10 patients with double grafts, one to an occluded and one to a non-occluded artery, there were 7 with one blocked graft, in each case to the non-occluded artery. In the other 3 both grafts were patent. $A$ watershed was shown at angiography in one patient with a graft inserted into a stenosed artery; the distal run-off appeared good, but reflux of the contrast up the coronary artery into the aorta occurred when injecting into the graft, and vice versa. This watershed may operate to a minor degree in all grafts inserted into non-occluded arteries, and by causing stasis at the anastomosis, could explain the higher incidence of graft occlusion in this group. Ligation of the coronary artery proximal to the anastomosis may therefore be necessary to achieve the highest patency rate.

Aortocoronary saphenous vein grafting is now a routine procedure in the treatment of severe angina caused by coronary atherosclerosis. Symptomatic relief is achieved in most cases (Morris et al., 1972), though the effect of the operation on life expectancy is still undetermined. Assessment of graft patency by angiography, carried out in large numbers of patients at varying intervals after cperation (Grondin et al., 1972; Flemma et al., 1972; Rösch et al., 1972), shows a patency rate comparable to the rate of symptomatic relief. Of several factors that may contribute to graft occlusion, Grondin et al. (1972) found the flow in the graft measured at operation and the size of the grafted artery to be the most important.

Grafting is often followed by a rapid increase in the coronary obstruction proximal to the graft (Malinow et al., 1973; Aldridge and Trimble, 1971), and this occurs more quickly than would normally be expected without surgical intervention (Ben-Zvi et al., 1974). It is assumed to be due to the sudden reduction in flow through the proximal coronary artery which Furuse et al. (1972) have shown to occur experimentally.

The study reported here was prompted by an observation in the case of a patient being investigated 24 days after vein graft surgery (Case 9). The

Received 18 August 1975. graft had been inserted into the right coronary artery, which had a severe proximal stenosis but a good distal run-off. Contrast injected into the graft passed not only into the distal lumen of the coronary artery, which appeared widely patent, but also retrogradely into the proximal lumen, and a little was eventually seen to reflux into the aortic root through the coronary orifice, whereas with contrast injected into the right coronary orifice the opposite was seen to occur-contrast filled the graft retrogradely and refluxed into the aorta.

Though this phenomenon of total flow reversal was clearly caused by the altered haemodynamics induced by the contrast injection it did suggest that the site of the anastomosis could act as a watershed, and that during the normal cardiac cycle there might be some phasic reversal of flow which would predispose to thrombosis. The study was therefore undertaken to see if graft patency was related in any way to the preoperative state of the coronary arteries; for, by this reasoning, grafts inserted into arteries with an incomplete proximal obstruction might be expected to have a higher occlusion rate compared with those inserted into the distal lumen of a totally blocked vessel.

Patients and methods

Out of a total of $\mathbf{2 1 5}$ patients who had one or more aortocoronary saphenous vein grafts inserted at the 
TABLE Angiographic findings in 50 patients before and after insertion of aortocoronary saphenous vein grafts

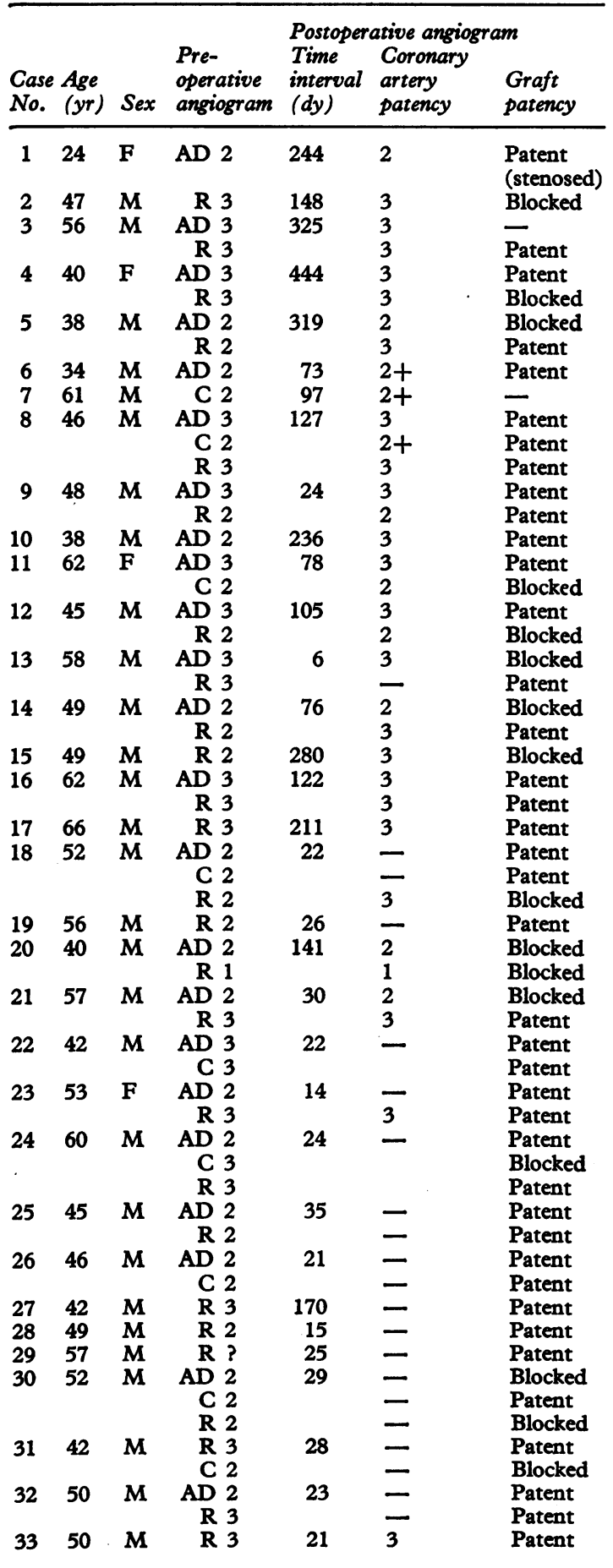

TABLE Continued

\begin{tabular}{|c|c|c|c|c|c|c|}
\hline $\begin{array}{l}\text { Case } \\
\text { No. }\end{array}$ & $\begin{array}{l}\text { Age } \\
(y r)\end{array}$ & Sex & $\begin{array}{l}\text { Pre- } \\
\text { operative } \\
\text { angiogram }\end{array}$ & $\begin{array}{l}\text { Postoper } \\
\text { Time } \\
\text { interval } \\
\text { (dy) }\end{array}$ & $\begin{array}{l}\text { ative angio } \\
\text { Coronary } \\
\text { artery } \\
\text { patency }\end{array}$ & $\begin{array}{l}\text { Graft } \\
\text { patency }\end{array}$ \\
\hline $\begin{array}{l}34 \\
35 \\
36\end{array}$ & $\begin{array}{l}53 \\
48 \\
34\end{array}$ & $\begin{array}{l}\mathbf{M} \\
\mathbf{M} \\
\mathbf{M}\end{array}$ & $\begin{array}{r}\text { R } 3 \\
\text { R } 2 \\
\text { AD } 3 \\
\text { R } 2\end{array}$ & $\begin{array}{r}14 \\
468 \\
260\end{array}$ & $\begin{array}{l}3 \\
3 \\
3 \\
2\end{array}$ & $\begin{array}{l}\text { Patent } \\
\text { Patent } \\
\text { Patent } \\
\text { Blocked }\end{array}$ \\
\hline 37 & 57 & $\mathbf{M}$ & R 2 & 410 & 3 & Patent \\
\hline 38 & 44 & $\mathbf{M}$ & $\mathrm{AD} 1$ & 21 & 1 & Patent \\
\hline 39 & 64 & $\mathbf{M}$ & R 2 & 21 & - & Patent \\
\hline 40 & 57 & $\mathbf{F}$ & C 2 & 328 & 3 & Patent \\
\hline 41 & 55 & $\mathbf{M}$ & $\begin{array}{r}\mathrm{R}- \\
\mathrm{AD}- \\
\mathrm{C}-\end{array}$ & 15 & E & $\begin{array}{l}\text { Patent } \\
\text { Patent } \\
\text { Blocked }\end{array}$ \\
\hline 42 & 54 & $\mathbf{M}$ & $\begin{array}{r}\mathrm{AD} 2 \\
\mathrm{R} 3\end{array}$ & 14 & $\overline{3}$ & $\begin{array}{l}\text { Blocked } \\
\text { Patent }\end{array}$ \\
\hline 43 & 50 & $\mathbf{M}$ & $\begin{array}{r}\mathrm{AD} 3 \\
\mathrm{R} 2\end{array}$ & 19 & $\begin{array}{l}3 \\
3\end{array}$ & $\begin{array}{l}\text { Patent } \\
\text { Blocked }\end{array}$ \\
\hline 44 & 69 & $\mathbf{M}$ & $\mathrm{AD} 2$ & 25 & - & Patent \\
\hline 45 & 59 & $\mathbf{M}$ & $\begin{array}{r}\text { AD } 2 \\
\text { R } 2\end{array}$ & 87 & $\begin{array}{l}2 \\
3\end{array}$ & $\begin{array}{l}\text { Blocked } \\
\text { Patent }\end{array}$ \\
\hline $\begin{array}{l}46 \\
47\end{array}$ & 62 & $\begin{array}{l}\mathbf{M} \\
\mathbf{M}\end{array}$ & $\begin{array}{r}\text { R } 3 \\
\mathrm{AD} 2 \\
\mathrm{R} 2\end{array}$ & $\begin{array}{r}337 \\
14\end{array}$ & $\frac{3}{-}$ & $\begin{array}{l}\text { Patent } \\
\text { Patent } \\
\text { Blocked }\end{array}$ \\
\hline 48 & 54 & $\mathbf{M}$ & $\begin{array}{rl}\mathrm{AD} & 2 \\
\mathrm{C} & 2 \\
\mathrm{R} & 2\end{array}$ & 29 & $\begin{array}{l}2 \\
2 \\
2\end{array}$ & $\begin{array}{l}\text { Patent } \\
\text { Patent } \\
\text { Patent }\end{array}$ \\
\hline 49 & 68 & $\mathbf{M}$ & $\begin{array}{r}\text { AD } 2 \\
\text { C } 2 \\
\text { R } 2\end{array}$ & 144 & $\begin{array}{l}2 \\
2 \\
2+\end{array}$ & $\begin{array}{l}\text { Blocked } \\
\text { Blocked } \\
\text { Patent }\end{array}$ \\
\hline 50 & 66 & $\mathbf{M}$ & $\begin{array}{rl}\mathrm{AD} & 3 \\
\mathrm{C} & 2 \\
\mathrm{R} & 1\end{array}$ & 229 & $\begin{array}{l}3 \\
3 \\
3\end{array}$ & $\begin{array}{l}\text { Patent } \\
\text { Patent } \\
\text { Blocked }\end{array}$ \\
\hline
\end{tabular}

Abbreviations: $\mathrm{AD}=$ left anterior descending coronary artery; $\mathbf{R}=$ right coronary artery; $\mathrm{C}=$ left circumflex coronary artery; $1=$ minor irregularity only with no lesion greater than 50 per cent; $2=50$ to 90 per cent stenosis; $3=$ total occlusion; and $2+=$ stenosis greater compared to preoperative angiogram.

National Heart Hospital between July 1970 and May 197450 (45 men and 5 women) were investigated by angiography between March 1971 and January 1975 to determine graft patency Their ages ranged from 24 to 69 years (mean 50). All survivors with a poor clinical result were investigated, a total of 16 patients. The other $34 \mathrm{had}$ a good result and the investigation formed part of a routine follow-up subject to the patient's consent. One graft had been inserted in 20 patients, two grafts in 22 patients, and three grafts in 8, making a total of 88 grafts. The angiograms were obtained within one month of operation in 25 of the patients and after a longer interval in the rest (up to 468 days, mean 214 days). The pre-operative coronary angiogram was not available for study in one patient, and after the postoperative investigation the state of two of the grafts remained uncertain. This left 82 grafts that were known to be either patent or occluded in 47 patients in whom preoperative coronary angiograms were available. 


\section{Results (Table)}

The overall patency rate of the grafts at the time of investigation was 70 per cent ( 61 out of 86 ). There was no significant difference in the incidence of patency between grafts inserted into any one of the three major coronary arteries but, as would be expected a higher proportion of grafts investigated within one month of operation was patent $(79 \%)$ compared with those investigated after a longer interval $(62 \%)$. There was, however, a difference $(P<0.05)$ in the patency rate between those grafts inserted into previously occluded coronary arteries $(87 \%)$ compared with those inserted into stenosed but non-occluded arteries $(62 \%)$, and this difference was more striking $(P<0.025)$ in the patients who were investigated more than a month after operation $(87 \%$ and $50 \%)$.

\section{Fate of grafts inserted into occluded coronary arteries}

Thirty grafts had been inserted into the distal lumen of arteries which were totally occluded proximal to the site of anastomosis. In all cases the distal lumen had been seen on the preoperative angiogram to fill retrogradely via collaterals. A distal endarterectomy was performed in 6 . Fifteen were investigated angiographically in less than one month and 15 at a longer interval ( 78 to 444 days, mean 286 days). In each group two grafts were occluded at the time of investigation, the other 13 (which included 5 out of the 6 with an endarterectomy) were patent with a run-off in the distal vessel which often appeared wider than on the preoperative angiogram.

\section{Fate of grafts to non-occluded arteries}

Fifty-two grafts had been inserted into arteries which were stenosed but not occluded proximal to the anastomosis. The stenosis was greater than $\mathbf{5 0}$ per cent in all but 2 , and greater than 75 per cent in most of the others. An endarterectomy was performed in 5. Twenty-eight of the grafts were investigated angiographically within one month of operation and 24 after one month (76 to 468 days, mean 242 days). In the early group 20 grafts were patent and 8 occluded; in the late group only 12 of the 24 grafts were patent. In this late group coronary angiograms in the 12 with patent grafts showed that the coronary artery proximal to the graft had become completely occluded in 8 , and in 3 the degree of stenosis was definitely greater. The other showed no change in the coronary artery, but there was a severe stenosis in the graft just proximal to the anastomosis. Of the 5 with an endarterectomy 2 grafts were patent and 3 occluded.

\section{Fate of double grafts, one to an occluded and one to a non-occluded artery}

Ten patients fell into this group. Three (Cases 11, 12 , and 36) were investigated more than one month after the operation (78, 105, and 260 days), in all of whom the graft to the non-occluded artery was blocked and that to the occluded artery patent. Of the other 7 investigated within one month both grafts were patent in 3 (Cases 9, 23, 32) and one of the grafts was blocked in 4 (Cases $21,31,42$, and 43), and in each instance it was the graft to the non-occluded artery.

\section{Discussion}

The inclusion of all survivors with a poor clinical result and only a small proportion of those who did well accounts for the low patency rate of 70 per cent in this series. The figure would undoubtedly have been much higher had more routine investigations been performed. The small number of endarterectomies does not allow a firm conclusion to be drawn, but in this series endarterectomy did not seem to influence graft patency one way or the other.

Insertion of a saphenous vein graft from the aorta into the distal lumen of an incompletely obstructed coronary artery creates a situation where the volume and velocity of flow in each is less than in the distal artery beyond the anastomosis. Furuse et al. (1972), in an experimental study, found that partition of flow was dependent on the relative diameter of the artery and graft and on the degree of stenosis in the proximal coronary artery. They also pointed out that the velocity of flow in the graft was inversely proportional to its diameter. Malinow et al. (1973) and Aldridge and Trimble (1971) noted that proximal coronary obstruction was often increased after grafting, and there seems general agreement that the reduction in flow is an important contributory factor to this development. The results of this study suggest that in addition there is a significantly lower patency rate of grafts inserted into incompletely obstructed arteries compared with those inserted into arteries with a proximal block. They also suggest that when a graft is inserted into an incompletely obstructed artery eventually either the graft or the artery will become occluded.

In view of the observation in Case 9, where reversal of flow was seen under angiographic conditions, it is tempting to postulate that when grafts 
are inserted into incompletely occluded arteries the watershed so created at the anastomosis causes stasis during some parts of the cardiac cycle and predisposes to occlusion of the coronary or the graft. If this is so the highest patency rate will be achieved only if the proximal coronary artery is ligated proximal to the anastomosis at the time of operation.

I thank the physicians and surgeons at the National Heart Hospital for permission to publish details of their patients, and $\mathrm{Mr}$ Donald Ross for helpful comments. I am also grateful to Dr. Anthony Rickards for statistical advice.

\section{References}

Aldridge, H. E., and Trimble, A. S. (1971). Progression of proximal coronary artery lesions to total occlusion after aorto-coronary saphenous vein bypass grafting. fournal of Thoracic and Cardiovascular Surgery, 62, 7.

Ben-Zvi, J., Hildner, F. J., Javier, R. P., Fester, A., and Samet, P. (1974). Progression of coronary artery disease. Cinearteriographic and clinical observations in medically and surgically treated patients. American fournal of Cardiology, 34, 295.
Flemma, R. J., Johnson, W. D., Lepley, D., Tector, A. J., Walker, J., Gale, H., Beddingfield, G., and Manley, J. C. (1972). Late results of saphenous vein bypass grafting for myocardial revascularization. Annals of Thoracic Surgery, 14, 232.

Furuse, A., Klopp, E. H., Brawley, R. K., and Gott, V. L. (1972). Hemodynamics of aorta-to-coronary artery bypass: experimental and analytical studies. Annals of Thoracic Surgery, 14, 282.

Grondin, C. M., Castonguay, Y. R., Lesperance, J., Bourassa, M. G., Campeau, L., and Grondin, O. (1972). Attrition rate of aorto-to-coronary saphenous vein grafts after one year. Annals of Thoracic Surgery, 14, 223.

Malinow, M. R., Kremkau, E. L., Kloster, F. E., Bonchek, L. I., and Rösch, J. (1973). Occlusion of coronary arteries after vein bypass. Circulation, 47, 1211.

Morris, G. C., Reul, G. J., Howell, J. F., Crawford, E. S., Chapman, D. W., Beazley, H. L., Winters, W. L., Peterson, P. K., and Lewis, J. M. (1972). Follow up results of distal coronary artery bypass for ischemic heart disease. American Fournal of Cardiology, 29, 180.

Rösch, J., Judkins, M. P., Green, G. S., and Kidd, H. (1972). Aortocoronary venous bypass grafts. Angiographic study of 84 cases. Radiology, 102, 567.

Requests for reprints to Dr. Simon Rees, National Heart Hospital, Westmoreland Street, London W1M 8BA.

\section{Symposium on cardiac pathology}

The British Cardiac Society held a Symposium on Cardiac Pathology at the University of Birmingham Medical School on 23 September 1975. The President, f. F. Goodwin, was in the Chair: the Scientific Secretary was E. G. F. Olsen and the Local Secretary was B. $L$. Pentecost. The following papers were given:

\section{Studies of Coxsackie viruses in heart disease}

Eleanor J. Bell

Ruchill Hospital, Glasgow, Scotland

\section{Pulmonary veno-occlusive disease}

Bryan Corrin

St Thomas's Hospital Medical School, London
Pathology of 'floppy' mitral valve

Michael Davies

St George's Hospital Medical School, London

\author{
Myocardial vasculature in normal and diseased \\ hearts \\ Geoffrey Farrer-Brown \\ Middlesex Hospital Medical School, London
}

Pathological aspects of cardiomyopathies with emphasis on the obliterative group

Eckhardt Olsen

National Heart Hospital, London 